\title{
Editorial:
}

\section{Teachers as Fountainheads of Curriculum Making: Challenges and Possibilities}

\author{
Julian Kitchen and Darlene Ciuffetelli Parker \\ Editors \\ Brock University
}

Decades ago, Joseph Schwab (1983) was particularly concerned with the problematic implementation of large-scale curriculum, and challenged the disproportionate force of policy makers in the development of subject matter that was then imposed on teachers and learners. Schwab argued that teachers should play a significant role in curricular decision-making due to their role as implementers of curriculum and their understanding of the learners in their classrooms. Schwab encouraged curricular decisions based on four commonplaces of: teacher, learner, subject matter, and milieu.

Clandinin and Connelly, building on Schwab's ideas, championed teachers as curriculum makers who actively work alongside students (Craig, 2011). They wrote that "teachers and students live out a curriculum [in which] an account of teachers' and students' lives over time is the curriculum, although intentionality, objectives, and curriculum materials do play a part (Clandinin \& Connelly, 1992, p.365). For them, Craig continues, it is a "question of teacher knowledge" (Connelly \& Clandinin, 2000) and teachers should be empowered to be curriculum makers to enhance the learning of students.

This volume of Brock Education explores various dimensions of curriculum, particularly the fountainhead roles teachers can play in improving the lives of learners. The authors of the five articles, while hopeful, point to the many challenges and pressures facing teachers as curriculum makers.

In 'Chinese immigrant parents' involvement in their children's school education: High interest but low action," Lan Zhong and George Zhou explore an important dimension of the educational milieu: the involvement of Chinese immigrant parents in schools. Demographics, language, culture and social dynamics are highlighted in a study that involved 12 Chinese immigrant couples whose children attended elementary schools. As the title suggests, Chinese immigrants seem highly involved in their children's schooling as it regards extra work and after school academic programs but less involved in co-curricular school-based activities. Reasons include: lack of time, language barriers and, unfamiliarity with the Canadian education system. The authors, who express concern about the 'high interest but low action' output of Chinese immigrant parents in this study, conclude that self-efficacy was a limitation for parents and that

Brock Education, Vol. 20, No. 2, Spring 2011, 1-3 
culture plays a large part in this. This article is very useful as it offers insights into the present day realities of the parents' role as well as the school's role as it applies to parental school-based involvement in a diverse society. Teachers and policy makers need to better understand the dynamics within various school communities in order to make curricular decisions that serve students from diverse backgrounds.

In "Literacy text selections in secondary school classrooms: Exploring the practices of English teachers as agents of change," Susan M. Holloway and Christopher J. Greig focus on the commonplace of subject matter. While secondary school English teachers in Ontario are given great latitude in the selection of literary works, the authors found that they often defaulted to status quo choices in order to avoid controversy. The authors draw attention to teachers acting as curriculum implementers-isolated and self-censoring-rather than as curriculum makers choosing subject matter that engages their students. They challenge teachers and policy-makers to create spaces in which teachers can feel empowered to use their professional knowledge to address the needs of students in a contemporary society.

In Lauren Segedin's article, "The role of teacher empowerment and teacher accountability in school-university partnerships and action research," the interplay between accountability and empowerment is observed more closely. Segedin puzzles over the ways in which a top-down project that encouraged action research in schools is both beneficial and problematic. In this project, secondary and elementary school teams of 36 teachers were led by a professor on 'how to do' action research on such topics as: literacy, student success, collaborative teacher lesson study, and character development. School district personnel acted as liaison persons to support the action research projects in eight schools. Segedin found that such projects offer teachers significant professional growth. At the same time, she found problematic the ways in which such projects can reduce teacher autonomy by holding them accountable to various stakeholders. This article is noteworthy for its currency on issues of school improvement and reform as they relate to teacher autonomy and decision making. It is not a simple answer but, as Segedin suggests, a complexity of issues that drive to the heart of what it means to be empowered as a curriculum maker in an era of accountability.

In "Embracing advocacy: How visible minority and dominant group beginning teachers take up issues of equity," Naomi Norquay and Marian Robertson-Baghel report on a four-year research project that followed graduates of a teacher education program from teacher certification through their first three years of teaching. Their inquiry into participants' narratives about advocacy efforts in both pre-service practicum placements and work as probationary teachers challenges the perception that the challenges of entering the profession discourage beginning teachers from engaging as change agents in equity work. The four graduates of a preservice teacher education program with an equity focus took significant steps towards creating equitable learning for marginalized students from the beginning of their careers. Unfortunately, they sometimes faced challenges due to inadequate support for such work in their schools. The authors argue that teacher education programs should be spaces in which new teachers can learn to build alliances and advocate for equity and justice in schools.

Arlene Grierson, Maria Cantalini-Williams, Taunya Wideman-Johnston, and Stephan Tedesco, in "Building scaffolds in the field: The benefits and challenges of teacher candidate peer mentorship," explore how teacher candidates in a concurrent four year program mentored 
novice first year concurrent education teacher candidates in their field placements. This innovative mentorship program was longitudinally researched and reports on how a collaborative inquiry-based learning model can benefit a reciprocal and relational mode of learning through practice and theory. Teacher candidates' perceptions led to further insights on school board partnerships and the sustainability model for such supports. This alternative model for the teacher education practicum shows promise as a means of building strong theory-practice links and empowering teachers to work collaboratively as curriculum-makers.

This collection of articles drew our attention to the complexities faced by teachers in schools. As Craig (2011) suggests:

The ever-widening dissonance between teachers' personal practical knowledge and others' prescriptions has served to increase the pitch of the tensions, further contributing to the "contested classroom space" (Craig, 2009) and increasing the volatility of a globally shifting teacher education landscape (Clandinin, Downey, \& Huber, 2009).

Understanding the tensions in the contested spaces of classrooms and schools is critical for teachers advocating for their students, as well as for teacher educators and policy-makers who seek to support teachers as curriculum makers and agents of change.

\section{References}

Clandinin, D. J., \& Connelly, F. M. (1992). Teacher as curriculum maker. In P. Jackson (Ed.). Handbook of curriculum. (pp. 363-461). New York: Macmillan.

Clandinin, D. J., Downey, C.A., \& Huber, J. (2009). Attending to changing landscapes: Shaping the interwoven identities of teachers and teacher educators. South Pacific Journal of Teacher Education, 37(2), 141-154.

Connelly, F. M., \& Clandinin, D. J. (2000). Teacher education-A question of teacher knowledge. In A. Scott \& J. Freeman-Moir (Eds.), Tomorrow's teachers: International and critical perspectives on teacher education (pp. 89-105). Christ Church, New Zealand: Canterbury Press.

Craig, C. (2009). The contested classroom space: A decade of lived education policy in Texas schools. American Educational Research Journal, 46(4), 1034-1059.

Craig, C. (2011). Narrative inquiry in teaching and teacher education. In J. Kitchen, D. Ciuffetelli Parker, D. Pushor (Eds.), Narrative inquiries into curriculum-making in teacher education (pp. 19-42). Emerald Publishing.

Schwab, J. J. (1983). The practical 4: Something for curriculum professors to do. Curriculum Inquiry, 13(3), 239-265.

Brock Education, Vol. 20, No. 2, Spring 2011, 1-3 